\title{
フレネル膜プリズムの視機能への影響について
}

\author{
鶴留 康弘 ${ }^{1)}$ ・阿曾沼早苗 ${ }^{1)}$ - 小嶋 由香 ${ }^{1)} \cdot$ 中前 美佳 ${ }^{1)}$

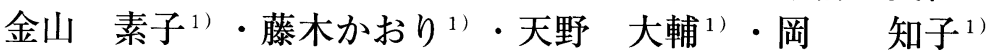 \\ 大澤 結 ${ }^{1)} \cdot$ 高田 雄介 ${ }^{1)} \cdot$ 別所建一郎 ${ }^{2)} \cdot$ 不二門 尚 ${ }^{1)}$ \\ 1) 大阪大学 \\ ${ }^{2)}$ 淀川キリスト教病院
}

\section{Effect of the Fresnel membranous prism on the visual function.}

\author{
Yasuhiro Tsurudome ${ }^{1)}$, Sanae Asonuma ${ }^{1)}$, Yuka Kojima ${ }^{1)}$, Mika Nakamae ${ }^{1)}$ \\ Motoko Kanayama $^{1)}$, Kaori Fujiki ${ }^{1}$, Daisuke Amano ${ }^{1)}$, Tomoko Oka ${ }^{11}$ \\ Yui Osawa ${ }^{1)}$, Yusuke Takada ${ }^{1)}$, Kenichiro Bessho ${ }^{2)}$, Takashi Fujikado ${ }^{1)}$ \\ 1) Osaka University \\ 2.) Yodogawa Christian Hospital
}

\section{要 約}

【目的】フレネル膜プリズムの視機能への影響を比較検討する。

【対象及び方法】対象は、視力や視機能に問題のない正常者 9 名 9 眼。年齢21 29 (24.8 2 3.12) 歳、

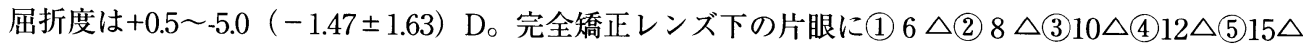
(6) $20 \triangle(730 \triangle の 7$ 種の膜プリズムを基底外方に貼付し、1、視力 $2 、$ 、ントラスト感度 (AULCSF) 3、グレアテスト 4、波面センサーによる眼球高次収差と、前方散乱係数（コントラスト法）を 測定し、それぞれ膜プリズムの有無による比較を行った。また、5、自覚的装用感についてのアン ケートも行った。

【結果】膜プリズム無しと比較して、1、2では $8 \triangle$ 以上の加入で有意な視力、AULCSFの低下 $(\mathrm{P}<0.01)$ が、 3 のグレア下では $12 \triangle$ 以上の加入から有意な感度低下がみられた $(\mathrm{P}<\sim 0.05)$ 。また 膜プリズム下でのグレアの有無による比較では、8 8 以上の加入でグレア有りの場合グレアなしと 比べて有意に感度が低下していた $(\mathrm{P}=\sim 0.05)$ 。眼球収差では、総高次収差（C3+C4）は $12 \triangle$ と 30 $\triangle$ で有意に増加し $(\mathrm{P}<0.05)$ 、前方散乱係数は $12 \triangle$ 以上の加入で有意な増加があった $(\mathrm{P}<0.05)$ 。 5 では、プリズム度が大きくなるにつれ自覚的装用感が悪化した。

【結論】8 8 以上のフレネル膜プリズムを処方する際には視力、コントラスト感度、グレア、散乱 などの視機能への影響を考慮する必要がある。

別冊請求先（５565-0871）大阪府吹田市山田丘 $2-15$

大阪大学医学部付属病院 眼科外来

Tel. 06-6879-5111 Fax. 06-6879-5476

E-mail : tsurudome@ophthal.med.osaka-u.ac.jp

Key words：フレネル膜プリズム、視力、コントラスト感度、グレア、前方散乱係数

Fresnel membrane prism, Visual acuity, Contrast sensitivity, Glare, Scatter index 


\section{Abstract}

【Purpose】 To examine the effect of Fresnel prism on visual function.

【Subject and method】 9 eyes of 9 subjects without ocular abnormalities were examined . Age ranged from 21 to 29 years $(24.8 \pm 3.12$, average $\pm S D)$ and the refraction ranged from +0.5 to -5.0 diopters $(-1.47 \pm 1.63)$. Membrane prism was fixed on the full-corrected lens. The power of Fresnel prisms were (1)6 (2)8 (3)10 (4)12 (5)15 (6)20 (7)30(Prism, Base out). We tested, 1: Full-corrected visual acuity, 2: Contrast sensitivity (Area Under Log Contrast Sensitivity Function, CSV-1000E), 3: Glare test (CSV1000-HGT) $4:$ Root Mean Square $(\mu \mathrm{m})$ value of total ocular aberration (Coma like (C3) aberration , Spherical-like (C4) aberration, C3+C4) and scatter index (SI) by Wavefront analyzer (TOPCON KR-9000PW) 5: Questionnaires of visual quality with prism.

【Results】Visual acuity and contrast sensitivity decreased significantly with prism $8 \triangle$ or more as compared with no prism $(\mathrm{P}<0.01)$.With glare light, contrast sensitivity decreased significantly with prism $12 \triangle$ or more compared without prism $(\mathrm{P}<\sim 0.05)$. Contrast sensitivity with glare light decreased significantly with prism $8 \triangle$ or more compared with it without glare light $(\mathrm{P}=\sim 0.05)$. $\mathrm{C} 3+\mathrm{C} 4$ increased with prism $12 \triangle$ and $30 \triangle$ significantly compared without prism $(\mathrm{P}<0.05)$. SI increased significantly with prism $12 \triangle$ or more $(\mathrm{P}<0.05)$. The subjective visual quality decreased with the increase of the power of prism.

【Conclusion】 When we prescribe Fresnel membrane prisms with a power more than $8 \triangle$, we have to consider the deterioration of visual function such as visual acuity, contrast sensitivity, glare.

\section{I 。緒言}

プリズムは光学的性質により、視軸の変更効 果（運動面）と、複視の矯正や両眼視発達（感 覚面）に使用されている。1) 臨床において、斜 視、弱視、視野欠損などの光学的視能矯正に重 用している。フレネル膜プリズム（以下膜プリ ズム）の材質である塩化ポリビニルクロライド （以下PVC）は、視力やコントラスト感度に影 響を与え、歪みや色分散が起こることが報告さ

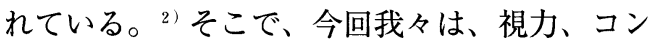
トラスト感度、グレア、収差、散乱などの観点 から、膜プリズムの視機能への影響を検討した。

\section{II. 対象と方法}

対象は、眼疾患がなく、正常な視力と視機能 を有するボランティア 9 例 9 眼（男性 2 例、女 性 7 例)、年齢は21歳～29歳（平均年齢 $24.8 \pm 3.2$ 歳)、屈折度数は $+0.5 \sim-5.0 \mathrm{D}$ (平均屈折度 数 $-1.47 \pm 1.63 \mathrm{D} ）$ であった。通常プリズムは麻 痺眼側に処方することから ${ }^{3)}$ 完全矯正下の片眼 (非優位眼) に、3M Health Care社製 6、8、
10、12、15、20、30（以下(1)、(2、 (3)、(4)、 5) 6、（7)）の 7 種類の膜プリズムを基底外方に貼 付し、優位眼を遮閉し単眼視において膜プリズ ムが無い時と有る時の、視力、コントラスト感 度、グレアテスト、Hartmann-Shack波面セン サーによる眼球収差、前方散乱係数を測定して 結果の比較検討を行った。また屋外と屋内での 自覚的装用感のアンケートを行った。

コントラスト感度はVector vision社CSV$1000 \mathrm{E}$ 用いて明所にて検查距離 $2.5 \mathrm{~m}$ で測定し た。この装置ではフェース部分の輝度は常に $85 \mathrm{~cd} / \mathrm{m}^{2}$ に自動補正される設定になっており、 3、6、12、18cycles/degreeの周波数のコント ラスト感度を測定することができる。各周波数

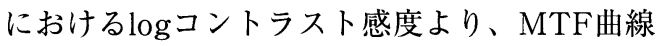
で囲まれる部分の面積である area under the log contrast sensitivity（以下AULC S F）を算出し 比較した。

グレアテストは、CSV-1000にハロゲンライト を取り付けた装置であるCSV-1000HGTを用い て、暗室にて縞視標チャートであるCSV-1000E を $2.4 \mathrm{~m}$ の距離で測定した。グレア刺激が無い時 と、最大グレア負荷の条件下で6cycles/degree 
のみのコントラスト感度を測定し、 $\log コ$ みラ スト感度を算出した。背景輝度は $114 \mathrm{~cd} / \mathrm{m}^{2} に$ 固 定され最大グレア時の光度は 29 万 $\mathrm{cd} / \mathrm{m}$ であっ た。

眼球波面収差は、TOPCON社 Wavefront analyzer KR-9000PW波面センサーを用い暗所 にて測定した。収差量は、計測した波面を Zernike展開して得られた係数の 2 乗の総和を求 め、その平方根root means square (RMS) と

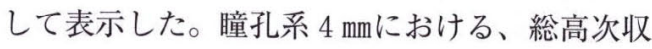
差 $(\mathrm{C} 3+\mathrm{C} 4=$ コマ様 + 球面様 $) 、 コ マ$ 様収差 (C3)、球面様収差（C4）それぞれのRMSを計 測し、散乱の定量法として、KR-9000PWに搭載 されているコントラスト法4) による前方散乱係 数測定のプログラムを用いた。

コントラスト法による前方散乱係数とは、 Hartmann像の中央 $4 \mathrm{~mm}$ 領域の点像（12個）に ついて、周辺 $0.6 \mathrm{~mm}$ 領域の背景との輝度を比較 し、12点分の平均を算出した数值であり、 Hartmann像から、ぼやけをパラメータ化した ものである。散乱係数は、コントラストの逆数 であるため、值が大きいほど前方散乱が大きい ことを表す（図 1)。

検討にあたり、膜プリズムにより角膜頂点が 偏心されるため角膜系の収差の検討は除外した。 また、矯正レンズによる眼球全体の収差、前方 散乱係数値への影響はなかった (Paired t-test) ことを記しておく。

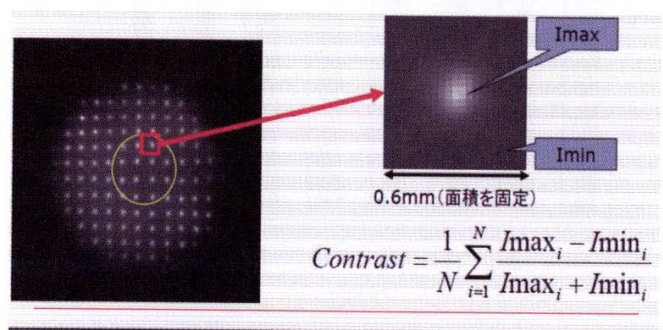

図 1 前方散乱係数（コントラスト法）

コントラスト法による前方散乱係数は、 Hartman $\mathrm{n}$ 像の中央 $4 \mathrm{~mm}$ 領域の点像（12個） について、周辺 $0.6 \mathrm{~mm}$ 領域の背景との輝度を比 較し、12点分の平均を算出した值である。最 低輝度 (Imin) は収差の影響はないと考えら れている。コントラストの逆数をとるため、 值が大きいほど前方散乱が大きいということ になる。
自覚的装用感については、晴天時の屋外（12 時から15時）と、屋内の視力検查室内における 装用感について尋ねた。感想の多かった、「ぼ やけ、反射、像の湾曲・歪曲、色の出現、空間 定位の誤認」の 5 項目を抽出し、膜プリズムの 度数ごとに、「 1 感じない、 2 やや感じる、 3 感じる、 4 明らかに感じる、 5 強く感じる」の 5 段階にわけて評価を行った。実際の処方は子 どもが対象であることも多く、膜プリズムの光 学的補正以外の効果（見え方）についての自覚 的な評価は聞き出せないことが多い。今回はこ の変化につき改めて自らで確認し、その知見を 生かしたいと考え検討した。

統計学的解析は、One Way ANOVA repeated measure、Wilcoxon Signed Rank Test、Paired t-testで検討をおこない、 $\mathrm{P}<0.05$ を有意とした。

\section{III. 結果}

1、視力

膜プリズム無しでの矯正視力は全例log MAR0.18であり、膜プリズム装用においては、(1)0.13(2)-0.04(3) 0 (4)0.06(5)0.19(6)0.28(7)0.42であっ た。膜プリズム無しと比較して(2) $(8 \triangle)$ 以上 の加入において有意な視力低下がみられた $(\mathrm{P}<0.01$, One Way ANOVA repeated measure $)$ (図 2 )。

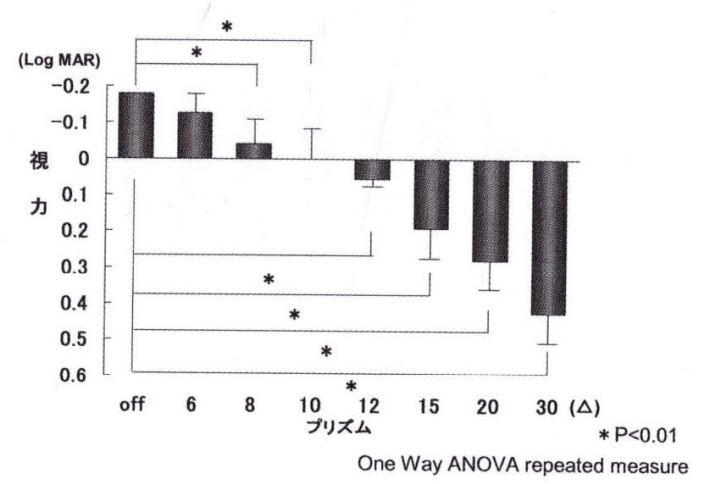

図 2 視力の比較

視力は $\log$ MARで表している。プリズム無し と比較して、8 $\triangle$ 以上の膜プリズム装用にお いて有意に視力が低下した（ P < 0.01, One Way ANOVA repeated measure)。 
2、コントラスト感度

膜プリズム無しでのAULCSFは1.54であり膜 プリズム装用下では(1)1.45(2)1.38(3)1.3(4)1.27(5) 1.22(6)1.1700.97であった。(2)（8 $\triangle ）$ 以上の度 数において、有意なコントラスト感度の低下が

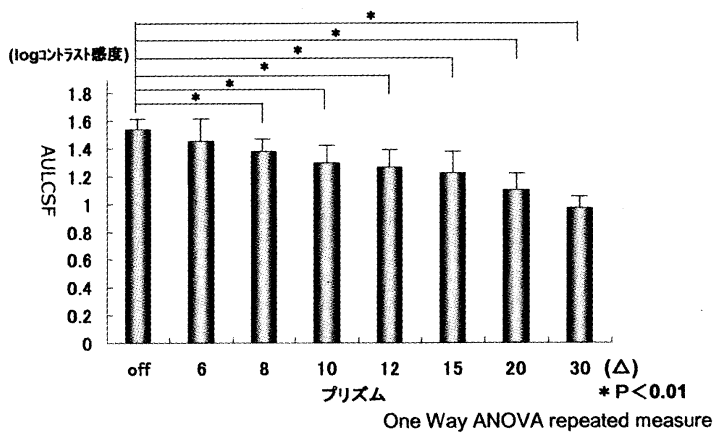

図 3 コントラスト感度 (AULCSF) の比較 プリズム無しと比較して、8 8 以上の膜プリ ズム装用において有意にコントラスト感度が 低下した $(\mathrm{P}<0.01$, One Way ANOVA repeated measure)。

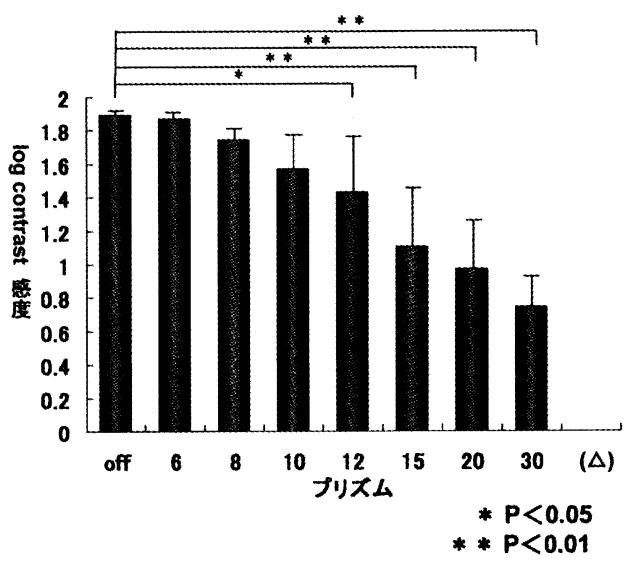

One Way ANOVA repeated measure

図 4-aグレア刺激負荷後のコントラスト感度の 比較

グレア刺激負荷後、プリズム無しと比較 して、12 12 以上の膜プリズム装用におい て有意にコントラスト感度が低下した (4) $\mathrm{P}<0.05$, (5)(6)(7) $\mathrm{P}<0.01$, One Way ANOVA repeated measure)。
みられた $(\mathrm{P}<0.01$, One Way ANOVA repeated measure)（図 3 )。

3、グレアテスト

グレア刺激下における、膜プリズム無しと、 各膜プリズム装用下での $\log$ コントラスト感度の 比較を示す（図 $4-\mathrm{a}$ )。グレア刺激負荷後、 膜プリズム無しのlogコントラスト感度は、1.89 であり、膜プリズム装用においては(1)1.87、(2) 1.74、(3)1.57、(4)1.43、(5)1.11、600.97、700.74で

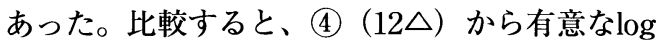
コントラスト感度の低下がみられた（4) $\mathrm{P}<0.05$ 、(5)(6)(7) $\mathrm{P}<0.01$, One Way ANOVA repeated measure)。次に各プリズム度数における、グレ ア刺激前後の $\log$ コントラスト感度を比較した結 果を示す（図 $4-\mathrm{b}$ )。グレア刺激無しの膜プ リズム無しの $\log$ コントラスト感度は $1.97 て ゙$ 膜プ リズム装用においては(1)1.97、(2)1.91、(3)1.76、 (4)176、(5)1.62、(6)1.52、(7)1.26であった。比較 すると、(2)（8 $\triangle ）$ から有意な低下がみられた (2)(3)(4)(5) $\mathrm{P}=0.05 、$ (6)(7) $\mathrm{P}=0.01$, Wilcoxon

\section{ログレアなし ログレアあり}

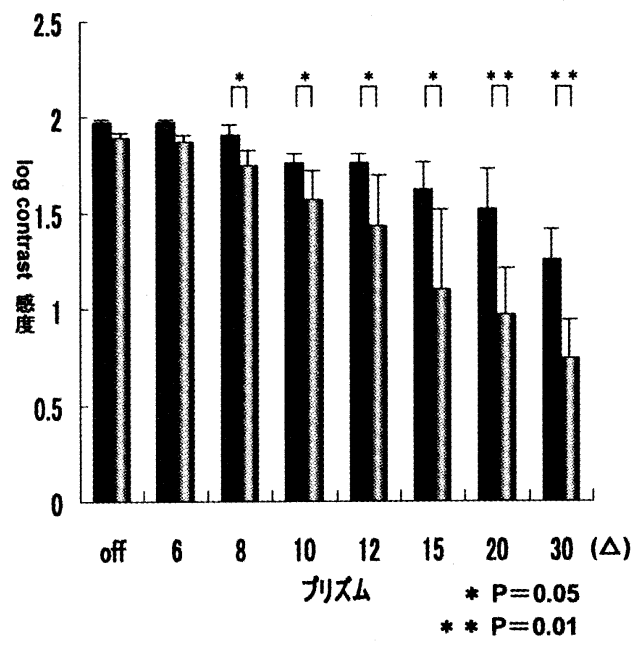

Wilcoxon Signed Rank Test, Paired t-test

図 $4-\mathrm{b}$ プリズム装用下における、グレア刺激前 後のコントラスト感度の比較 各プリズム装用下における、グレア刺激 前後のコントラスト感度は $8 \triangle$ 以上にお いて有意な差がみられた（2)(3)(4)(5) p = 0.05、(6)(7) $\mathrm{P}=0.01$, Wilcoxon Signed Rank Test, Paired t-test)。 
Signed Rank Test, Paired t-test)。

4、Hartmann-Shack波面センサー

$10 \triangle$ 装用下の一例を図 5 に示す。マイヤー像
は、プリズムと矯正レンズの反射がみられリン グが完全に投影されていない箇所がある。角膜 の収差は除外した。Hartmann像は、ぼやけて

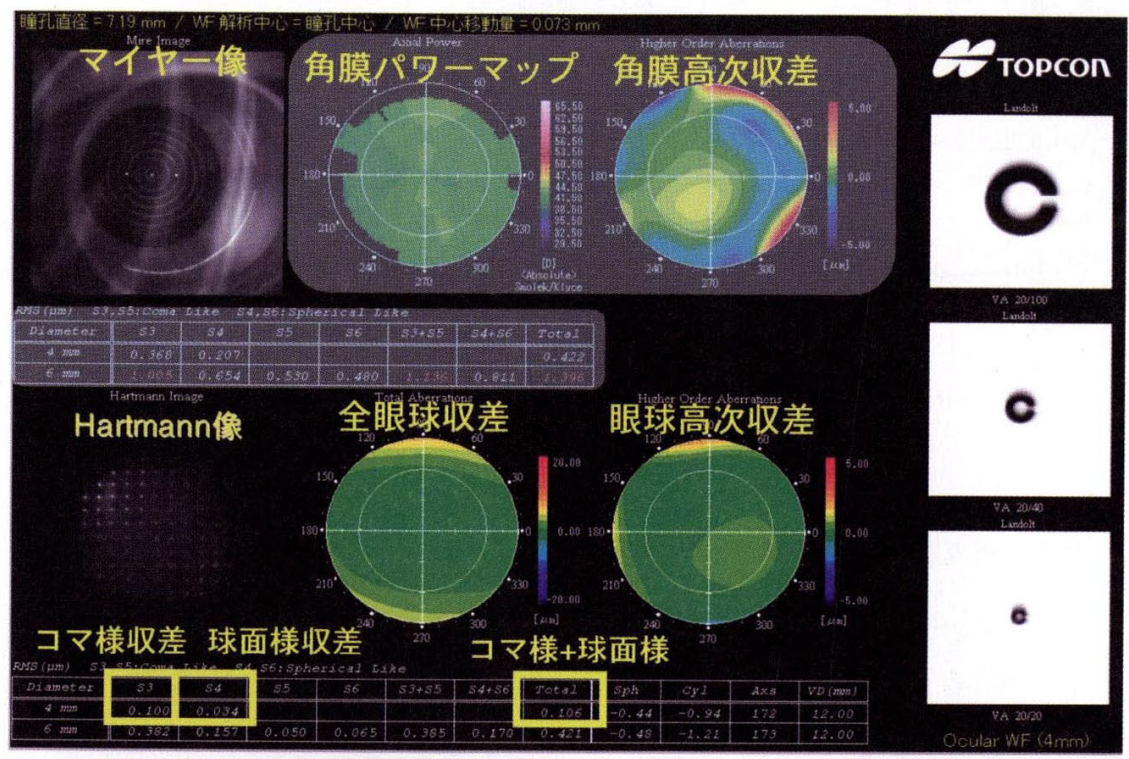

図 5 10 のの膜プリズムを基底外方に装用した時の波面センサー画面

左上のマイヤー像は、膜プリズムと矯正レンズの反射のためリングが完全には映っ ていない。角膜の収差は除外した。Hartmann像はばやけており、またドットの形 状、輝度がばらついている。

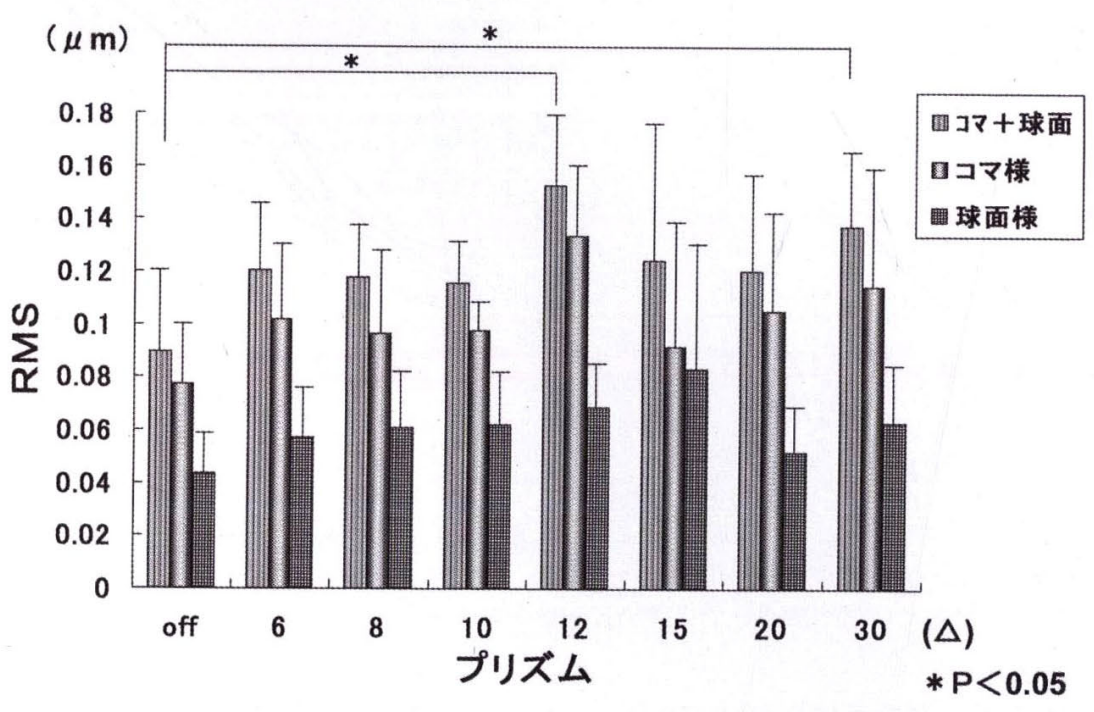

* One Way ANOVA repeated measure

四 6 眼球全体のRMS（コマ様+球面様、コマ様、球面様）の比較

プリズム無しと比較して、コマ様+球面様収差のみ $12 \triangle と 30 \triangle$ 装用下で有意に収 差が増加した $(\mathrm{P}<0.05$, One Way ANOVA repeated measure)。 


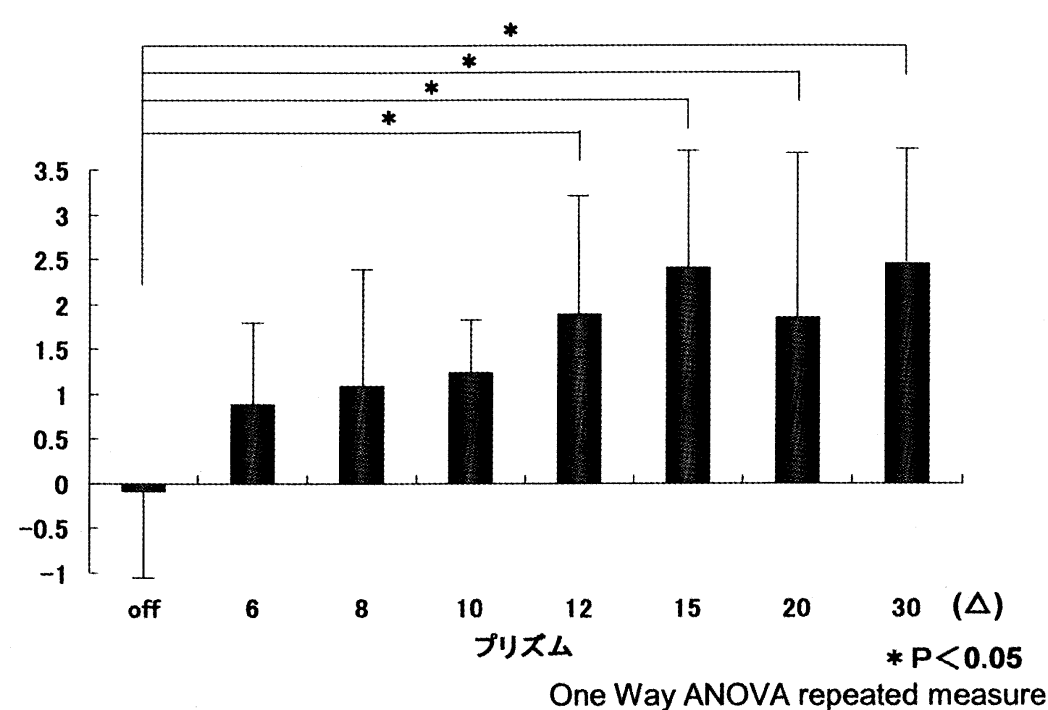

図 7 前方散乱係数の比較

プリズム無しと比較して、12 数が増加した（ $\mathrm{P}<0.05$, One Way ANOVA repeated measure)。

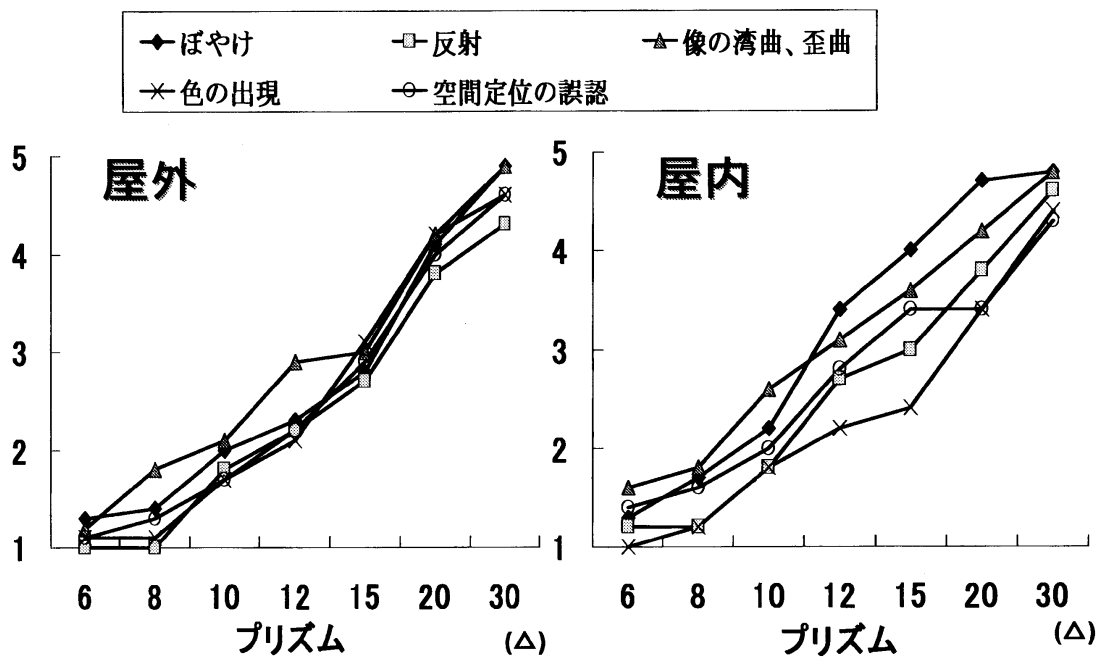

図 8 自覚的装用感

屋外、屋内での装用感を「 1 感じない、 2 やや感じる、 3 感じる、 4 明らかに感 じる、 5 強く感じる」の 5 段階で評価を行った。数値が大きいほど違和感が強い

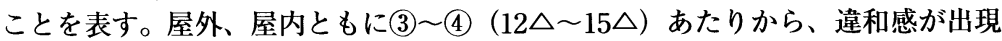

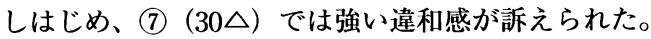

おり、ドットの形状、輝度がばらついていた。 眼球全体のRMSを膜プリズム無しと比較する と、コマ様＋球面様収差において(4) (12வ) (7) $(30 \triangle)$ のみに有意なRMSの増加がみられた。 コマ様のみ、球面様収差のみでは有意な差は認
められなかった（ $\mathrm{P}<0.05$, One Way ANOVA repeated measure)（図 6 ）。

膜プリズムなしの前方散乱係数は、 $-0.09 \pm$ 1.635で散乱が低いことを示す。装用下では(1) $0.88 \pm 1.63$ (2) $1.09 \pm 1.53(3) 1.23 \pm 0.81$ (4) $1.88 \pm 1.69$ (5) 
$2.40 \pm 1.55(6) 1.85 \pm 1.51(7) 2.45 \pm 1.33$ であった。膜

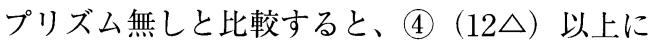
おいて有意な増加がみられた $(\mathrm{P}<0.05$, One Way ANOVA repeated measure) (図 7 )。 5 、自覚的装用感

屋外、屋内の装用感の評価を示したグラフを 眓 8 に示す。膜プリズムの度数が強くなるにつ れ、全ての項目での装用感の悪さが増している。 5 段階中、 3 以上を示したのは、屋外、屋内と

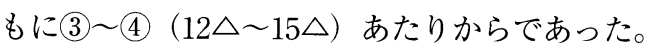

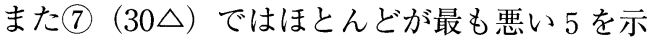
していた。

\section{IV. 考按}

フレネル膜プリズムはその光学的特性から視 能矯正に頻繁に利用されるアイテムである。長 所は多いが、意図に反して視機能を低下させて しまう短所も持っている。どの程度の度数でど のような視機能の低下がおこるのであろうか。 今回我々は、フレネル膜プリズムが視機能に及 ぼす影響について、いくつかの観点から検討を 行ってみた。

視力、コントラスト感度は、膜プリズム無し と比較すると、(2)（8 $\triangle$ ） から有意な低下がみ られた（P<0.01）（図 2，3）。過去の報告で は、Veronneau-Troutmanが「12 $\triangle$ 以上で有意

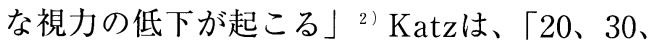
$40 \triangle$ 装用した例では、有意な視力低下をきた す。またAULCSFにてコントラスト感度の低下

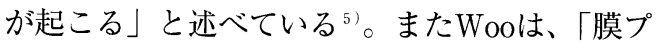
リズムのPVCの色分散が原因で、10 0 以上で十 分に視力、コントラスト感度が低下する。また 空間周波数ごとに比較すると、低周波数領域で は、変化はさほどないが、 $15 \triangle$ 以上で高周波数 領域のコントラスト感度が低下する」と報告し ている ${ }^{6)}$ 。視力やコントラスト感度が低下する 膜プリズムの度数について、今回の我々の結果 と概ね一致すると考えられる。高周波数域のコ ントラスト感度は視力との相関が高いが、今回、 低〜中間周波数域である6cycles/degreeにおい ても、コントラスト感度の低下がみられたこと から、膜プリズム装用時のコントラスト感度を
確認する重要性が示唆された。また、自覚的装 用感として「ぼやけ」が被験者全員から訴えら れたが、これは、膜プリズムの度数が大きくな ることにより、視力とコントラスト感度が低下 することが、ぼやけの自覚に反映されていると 考えられた。

膜プリズム装用下での高次収差について、波 面センサーを用いて解析を行った結果、(4)（12 $\triangle ）$ と(7) $(30 \Delta)$ のみで、コマ様＋球面様収差 において有意な増加が認められただけであった (図 6 )。膜プリズムがあることで、RMSの増加 はみられるが、プリズム度数とRMSに有意な相 関はなった。プリズムによる収差は 1 次の低次 収差の範囲内であることが理想的であるが、波 面センサーで測定された 2 次以上の高次収差に は特定の傾向は見られなかったことから、膜プ リズム装用における高次収差の影響はほとんど ないと考えられた。

グレアテストや前方散乱係数と、「反射して 見える」という自覚的な感想から、光の反射、 散乱について考えてみる。まず反射を訴えるこ とは、Veronneau-Troutmanの「プリズムの臨 界角（全反射を起こす最小の入射角）を通過す ると光は減少するが、他の入射角からは多くの 光を受ける」 ${ }^{2)}$ との報告や、臨界角を越えると 光は境界面で全て反射される》性質があること から、説明することができる。

グレアテストでは、グレア刺激負荷後の $\log コ$ ントラスト感度を、プリズム無しで比較すると、

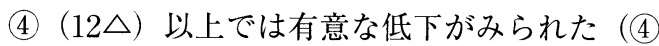
$\mathrm{P}<0.05 、(56$ (6) 7 P < 0.01)。膜プリズム装用下 でグレア刺激前後の比較をすると(2) $(8 \triangle)$ か ら有意な低下がみられた (2)(3)(4)(5) $\mathrm{P}=0.05$ 、 (6) (7) $\mathrm{P}=0.01)$ 。CSV-1000HGT測定中、光の散 乱や反射で、縞視標がかくれてしまうことがあ った。検査中は、被検者に、head tiltなどさせ て最大限見える努力を促して測定した。しかし 膜プリズムの度数が大きくなるにつれ屈折角も 大きくなり、主断面も増えることで反射が増加 し、結果としてコントラスト感度が低下したと 推察される。

次に、散乱についてだが、膜プリズム装用下 のHartmann像は背景が明るく、点像がぼやけ 
ている例が多かった。三橋らはHartmann像の 点像のぼやけから散乱を検証し、「瞳孔系 $4 \mathrm{~mm}$ の前方散乱係数は、白内障群 $(5.04 \pm 3.06)$ で

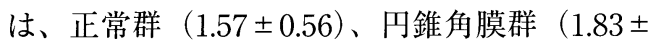
0.79）よりも、前方散乱係数が大きく、高次収 差と、光散乱には相関がない」5) と報告した。 今回の検討によると、多少のばらつきはあった

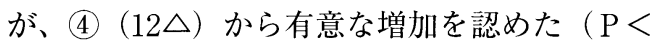
0.05）。この方法では背景輝度を比較しているた め、収差に関係なく測定ができることから、膜 プリズムにより散乱が生じていると考えられる。 しかし、散乱に関しての確定的な評価法はない ため、他の評価法も必要だと思われる。また、 最も大きい $30 \triangle$ 加入でも散乱値は $2.45 \pm 1.33$ あ゙あ り、程度の差はあるが白内障眼ほどの散乱の増 加は見られないようである。この散乱が視機能 にどう影響するのか。症例は異なるが、過去に 関本らの「白内障眼において最大グレア刺激に より強い散乱が起こりコントラスト感度が低下 する」 ${ }^{8)}$ との報告や、不二門らは「白内障眼の 前方散乱係数、後方散乱係数、高次収差が、眼 球光学系の劣化に関係する」9) と述べている。 これを受けて、散乱がコントラスト感度の低下 やその他の視機能に関係することは矛盾しない と考えられる。

膜プリズム装用下で、建物や足元のタイルが 歪んだり、拡大されて見えたこと、視線を変え ることにより、湾曲の程度が頂点と基底で異な つていた。また度数が大きくなるにつれ、変化 が増していった。これらは、Ogleの 5 つの歪み (水平方向への拡大、垂直線の湾曲、非対称な 水平方向への拡大、垂直方向への拡大、側面の 角度に扮ける垂直方向の拡大の変化） ${ }^{10)}$ と一致 していた。これらの違和感が視力やコントラス 卜感度などといった視機能にどう影響している かは不明だが、像の湾曲、歪曲、拡大が生じる ことにより、例を挙げると歩行やデスクワーク などにも支障が生じることが推察される。また、 悪心、頭痛、疲労を自覚する感想もあったこと から、見え方以外にも影響を及ぼすことが、考 えられた。

色の出現は、光の波長により屈折率が変化す る分散によるものである。物体の基底側は黄
色に見え、頂点側で青く見えたという感想も分 散とスペクトルの関係から、説明することがで きる。中村は「色分散はプリズム度とアッベ数

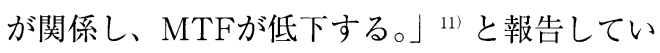
る。色分散量に関しては、検討していないため 今後の研究課題とする。

総括すると、膜プリズム（PVC）は、(2) $8 \triangle$ 以上の負荷で視力、コントラスト感度を低下さ せ、12 12 以上にるとグレア感度も低下した。 また、ぼやけ、反射、像の湾曲・歪曲、色の出 現、空間定位の誤認など見え方に変化を及ぼし、 膜プリズムの度数が大きくなるほど、悪化する。 これらは、過去の報告と同様であり、他覚的な 結果と自覚的な感想が一致していた。そして、 新たに高次収差には影響がほとんどないこと、 グレアテストにより反射が、また波面センサー により前方散乱が $12 \triangle$ 以上の負荷において視機 能低下に影響していることが示された。

今回は膜プリズムを非優位眼に貼り、単眼視 における視機能の影響を検討した。臨床現場に おいて膜プリズムを処方する際は両眼視の状態 を把握することが重要であり、装用可能なプリ ズム度数もさまざまである。今後は今回の知見 を臨床で活用し検討を続けていく予定である。

\section{参考文献}

1) Suzanne Veronneau-Troutman, 不二門尚, 斉藤純子訳：プリズムと斜視. 83-84文光堂, 東京, 1998

2) Suzanne Veronneau-Troutman: Fresnel prism and their effects on visual acuity and binocularity. Trans Am Ophthalmol Soc 76 : 610-653, 1978

3 ）矢ケ崎悌司：プリズム処方のための検査. 丸 尾敏夫（編）：眼科プラクティス 5１90-194， 文光堂, 東京, 2002

4) Mihashi Toshifumi, Hirohara Yoko, Bessho Kenichiro, Maeda Naoyuki, Oshika Tetsuro, Fujikado Takashi : Intensity Analysis of Hartmann-Shack Images in Cataractous, Keratoconic, and Normal Eyes to Investigate Light Scattering. Japanese Journal of 
Ophthalmology. (0021-5155) Vol. 50, 4号, 323333, 2006

5 ) Milton Katz : Visual acuity though Fresnel, refractive, and hybrid diffractive/refractive prism. Optometry. 75, (8), 503-511, 2004

6 ) George C. Woo, Fergus W. Cambel : Effect of Fresnel prism dispersion on contrast sensitivity function. Opthalmic Physiol Opt. Vol. 6, No4, 415-418, 1986

7 ) 西信元嗣: 眼光学の基礎. 反射と屈折 $2-$ 5 ，金原出版株式会社，東京，1990

8 ) 関本紀子, 阿曽沼早苗, 岡井佳恵, 田中仁菜,
水野真由美, 不二門尚, 他：グレア光照射の 瞳孔系及び、コントラスト感度に与える影響. 日視会誌 32巻：109-113，2003

9 ）不二門尚, 前田直之：眼科検查診断法 新し い視機能評価システムの開発. 日眼会誌 108 巻 12 号 : 809-822, 2004

10) Ogle KN : Distorsion of the image by ophthalmic prisms. Ach Ophthalmol 47 : 121131, 1952

11）プリズム色分散によるMTFの低下についての 研究wwwl.ocn.ne.jp/〜shojido/pages/prism/ prism.htm 